\title{
Problematizing Situational Irony: A Critical Study on Hardy's An Imaginative Woman
}

\section{Ironi Situasional: Sebuah Studi Kritis tentang An Imaginative Woman Karya Thomas Hardy}

\author{
Asmaul Qusnaini, M. Misbahul Amri*, Inayatul Fariha \\ Universitas Negeri Malang, Jl. Semarang No. 5 Malang, Jawa Timur, Indonesia \\ *Penulis korespondensi, Surel: m.misbahul.fs@um.ac.id
}

Paper received: 12-10-2021; revised: 25-11-2021; accepted: 30-11-2021

\begin{abstract}
The purpose of this paper is to comprehend how situational irony in Thomas Hardy's short fiction entitled An Imaginative Woman conceptualized a tension of irony in readers' perceptiveness. To this aim, this study tries to examine the relation among aspects: the story plot, characterizations, focalizations, and narrator's comments. The narration of this short story shows there are two representation levels of irony: (1) the story level which contains: the sequence of Ella's ironic events and portrayal of victimized characters; (2) the narrative level consists of: numerous focalizations that are entangled with formulation of perspective and narrator's intrusive comments that becomes the embodiment of narrator's unreliability. This paper suggests that situational irony signifies the dynamic strategy of narrative in order to manifest the tension of irony within the story and its representation. Additionally, this strategy emphasizes readers' compatibility with the irony of the narrative.
\end{abstract}

Keywords: narrative; situational irony; focalization; intrusive narrator

\begin{abstract}
Abstrak
Makalah ini bertujuan untuk memahami bagaimana ironi situasional dalam cerita pendek $A n$ Imaginative Woman karya Thomas Hardy mengkonseptualisasikan ketegangan ironi dalam persepsi pembaca. Untuk itu, penelitian ini mencoba mengkaji secara kritis hubungan antar aspek berikut: alur cerita, penokohan, fokalisasi, dan komentar narator. Narasi cerpen ini menunjukkan terdapat dua tingkat dalam representasi ironi: (1) tingkat cerita, yakni memuat: urutan peristiwa ironis yang terjadi terhadap Ella dan penggambaran karakter yang dijadikan korban; (2) tingkat naratif, terdiri dari: beberapa macam fokalisasi yang berhubungan dengan perumusan perspektif dan komentar narator yang mengganggu sebagai perwujudan ketidakpercayaan pada narator. Makalah ini menunjukkan bahwa ironi situasional menandakan kedinamisan strategi dalam narasi dalam mewujudkan ketegangan ironi baik di dalam cerita maupun cara merepresentasikan cerita. Selain itu, strategi ini menekankan kompatibilitas pembaca yang berperan penting untuk menjangkau ironi narasi.
\end{abstract}

Kata kunci: naratif; ironi situasional; fokalisasi; intrusi narrator

\section{Introduction}

An Imaginative Woman is Thomas Hardy's special short story because he once said it was the best short narrative he ever wrote (cited in Ray, 1997). Besides, in 1912, Hardy transfers this short story from Wessex Tales edition to Life's Little Ironies volume with his note of moving this short story to be more nearly its place (Hasan, 1982; Thomas, 2013). However, Thomas Hardy is well-known as a novelist (Riegler, 2009). His reputation as a novelist is brighter than as a short story writer which affects the sparse study on his An Imaginative 
Woman. This stimulates a curiosity for examining this short story with Hardy's special heed but gets scant attention.

The fact that An Imaginative Woman is transferred to the volume entitled Life's Little Ironies apparently indicates that the story contains irony. However, the depiction of Ella Marchmill as an aberrant female character in the story derives several studies focus on her and issues around her.Kohut disagrees with Ella's aberrant roles, he underlines the socio-cultural condition that Ella is under male superiority typically Victorian era (2011). Meanwhile, other critics tend to highlight Ella's way to react towards her condition. Vera (2012) finds Ella's experience of sexual pleasure and cognitive cultivation are responses for her stagnation towards her husband and marriage life. Besides, she also elaborates that Ella's chance to enjoy writing or reading poems indicates her liberation of her brevity to challenge the traditional norm of wife (Vera, 2012). This remark leads to further insight towards the significance of poetry in the story. Critics like Bernard (2013) and Lanza (2018) show the important role of poetry within the story. Bernard and Lanza share the same psychological lens to elaborate the significance of poetry related to Ella's emotional and mental condition.

All in all, Ella's significance cannot be a trivia of the story. Because the use of Ella is obviously stimulating several studies. However, the aim of the stimulation is more important to readers. Thus, Ella's ironic condition is formulated to gain readers' attention because its socio-cultural context tries to provoke society (Manzoor \& Zaidi, 2016). Then, the question leads to what ironic condition and how it is constructed in the narrative so it can achieve its aim of gaining readers' attention.

Taking more remarkable examination, Ginsburg (2012) elaborates the relation among literary creation, gender and poetic imagination that become the vital elements in the story. She explicates about all those elements are interconnected in the story. One of her findings that exciting for this study is about her defining of irony. According to her, irony in the story refers to the role of Nature with its power beyond Ella, William, and Trewe in case of childbearing (Ginsburg, 2012). She figures out that the power works as a twisted point for William's imagination about his child's resemblance. William is suggested by the resemblances to believe that Ella has affairs with Trewe which the last child is Trewe's son (Ginsburg, 2012). This renders dramatic tension because readers know what is true about the child. Besides, dealing with irony, Bernard (2013) brings it in her paper but in more lightly. She describes in her conclusion part that all of misery in the story is representation of Ella's irony of life that leads her into her tragic end. In opposite, Riegler gives a fully examination about irony in the story. Riegler (2009) finds that the irony in the story is in embodiment as cosmic forces that manipulates the character's destiny. This cosmic irony is produced from internal forces, external forces, and cosmic forces (Riegler, 2009). Internal forces refer to Ella's dreaming, delusion, and emotion, while external forces come from Ella's marriage. The cosmic forces are defined as ethereal power of God that formulating Ella's ironic fate (Riegler, 2009).

Accordingly, the apparent presence of irony in this short narrative of An Imaginative Woman suggests the discussion about it. Previous studies have explained the irony of life, cosmic irony or irony of fate, and dramatic irony in the story. However, this short narrative hints the tendency of creating irony whether by content, technique, or both in a concise form. This is more than numerous results that are inherently attached to irony in this short narrative like tragedy or drama. Therefore, situational irony emerges as a suitable point to be discovered 
in this short narrative. According to Čović (2018) situational irony is the field that tragic irony, cosmic irony, or dramatic irony are in its domain. Besides, short narrative is a literary form that is fitted with situational irony that takes place on the situation within the story or the context of the story.

\section{Methods}

\section{Situational Irony}

Situational irony is defined as "a condition" or "outcome of events" that "are seen to or felt to be ironic" (Muecke, 1962). This is also outlined as the contradiction between expectation and result (Muecke, 1962). Moreover, Muecke (1969) conceives that situational irony has two levels: 1) lower level and 2) upper level. Lower level indicates the irony explicitly known to the participants including the victims, while upper level recognizes irony implicitly and not necessarily known to all participants. The first level is designated with the presence of the victim as an apparent precursor. The victims, according to Colebrook (2004) is an agent who is innocent and ignores the irony that befell them. The upper level of irony allows the observer of irony, in this case his reader, to determine and reconstruct the irony in their perception and judgment (Miller, 2019). Thus, Lucariello and Mindolovich (1995) give the alternative for this double layered irony. They show the importance of twisted one's knowledge to yield ironic situations (Lucariello \& Mindolovich, 1995).

\section{Narratology}

Narratology is one branch field of structuralism which is characterized by its dominant concern with structure of narrative and the effects (Rudrum, 2002). A well-known critical thinker of narratology is Gerard Genette. Based on Rudrum (2002), Genette contributes to work out-performing original structuralists polarized between "story/histoire" and "narrative/discourse." He comes with the third additional dimension to it, which is the "narrating" itself that is written in Narrative Discourse. The story is defined as the set of events that is narrated in which the Saussurean linguistic concept as being the signified, while narrative or discourse refers to the manner of representation or in which as the signifier. According to Rudrum (2002), this dimension enables for differentiating not only between what is narrated and how it is narrated, but also by whom it is narrated. The narratology attempts to conceive in greater detail regular problems like point of view, focalization, and narrator's place.

Focalization is Genette's terminology which revisited the classical concept of point of view (Rimmon-Kenan, 2005). Based on de Jong (2014: 2), focalization refers to "emotional filtering and temporal ordering." When the point of view and similar terms are used, confusion regarding between perspective and narration often occurs, hence Genette gives a surprising alternative of focalization to dissipate this miss-understanding (Rimmon-Kenan, 2005). Moreover, according to Rimmon-Kenan (2005), focalization has a broadened idea than an optical connotation of point of view because of including the cognitive, emotive, and ideological orientation. Genette has distinguished focalization into zero focalization, internal focalization, and external focalization. Internal and external focalization is a set focalization that indicates a different amount of information.

Within internal focalization, it has distinguished into three sub-types: 1) fixed internal focalization which specific character tells everything from his point of view within story, 2) 
variable internal focalization refers to variable characters point of view used to tell the story normally sequentially from one to another character, 3) multiple internal focalization presents different point of views among various characters that told in the story (Bae, Cheong, \& Young, 2011). According to Genette, by using multiple internal focalizations, in particular, the same story can be repeatedly told with different perspectives of story characters (Genette, 1980). However, there is sometimes a story that uses the mixed types of them. In contrast to internal focalization, external focalization refers to the focalizers' limited information which is less than the characters (Kindt \& Muller, 2003). It excludes internal observation of states of mind. Therefore, Rimmon-Kenan (2005) suggests taking the rewritten part in a first-person view as the way to distinguish whether external or internal focalization. Lastly, zero focalization refers to unrestricted or unlimited perspectives towards the character in contrast to internal and external focalization. According to de Jong (2014), Genette's zero focalization is made for corresponding to Stanzel's idea of authorial situational narration that narrator authoritatively overbearing the story and characters in it since he can stare from above of the character doing, their mind, and the location it is take place.

\section{Intrusive Narrator}

Intrusive narrator, according to Phelan (2013), is defined as the way of narrating that allows the transference of the traditional impersonal narrator to the apparent narrator's voice. This way identically infers the development of modernist ideal narrator to an aesthetic utmost role of narrator. Furthermore, Rimmon-Kenan (2005) presents the characteristics of intrusive narrator chiefly in embodiment of narrator comments that conveys several values: interpretation, judgment, and generalization. Additionally, to serve those typical comments, there are several identifications such as direct address, self-reflexive statement, and stylistic expressivity as some typical identity. Those identical comments infer the narrator's personal insight or believe that sometimes it does not correlate with the story. The performance of an intrusive narrator hence shows the performance of authoritative status of the narrator to perform his personalization. Phelan (2013) describes more of the significance of the intrusive comments as a typical way to bring the rhetorical effects due to the execution towards characters and readers in expecting their involvement with their perception. The execution that Phelan's (2013) described is the automatic interrelation between readers into the fictional world that enhances their attachment because the narrator personalizes presence that maintains the guarantee of the authenticity status. Accordingly, narrator personae appear as the mediation for readers and character to stay on the same ground underneath narrator authority. This mediation comes as the result of a narrative process that creates mimesis effect (Nunning cited in Kindt \& Muller, 2003). In other words, the narrative process generates a realistic narrative form that stimulates the reader's direct communion with the narrator in a fictional world stage. The result, therefore, enhances readers' trustworthiness to the narrator due to the apparent pictorial view of the fictional world that the narrator has persuaded (Fludernik, 2004).

\section{Findings and Discussions}

\subsection{Story Level of Irony}

A sequence of ironic events is the representation of story level irony in the narrative of An Imaginative Woman. The story begins with Ella who feels unhappy with marriage because she has William, who is the opposite character, as her husband. At the same time, for healing 
herself from marital life, Ella decided to throw her eagerness into poetic creation, but she failed to compete or even imitate the works or level of the poet she adored. Following by some incidental events, Ella finds her poetic inclination shifts into sexual inclination towards the poet she admires, Trewe, but never meet at all and tragically ends in the poet's suicide. Interplaying between marital life and poetic creation represent the ironic events since Ella perceived the misery and unsatisfied result from the expectation. The series of one ironic event that followed by other ironic events arranged within a fictional world shows the story's level of irony (Rudrum, 2002).

Ella's marriage is the early stage of the ironic event. Marriage for Ella is something that is a culturally common or ordinary thing to take by human beings. Assuredly, marriage in the Victorian era is presented as the only way for women to live a decent life that will be accepted by society (Kohut, 2011). This is endorsed by the fact that Ella decided marriage because "the necessity of getting life-leased at all costs" which is "a cardinal virtue" (pp.3). In other words, this marital status becomes the common situation in that era as something that is supposed to happen. This "supposed-happening" infers Lucariello's "script" which means frequently enacted activities or conventional ones (Lucariello, 1994; Li, 2008). Furthermore, Lucariello (1994) emphasizes the point of "script" of carrying the general knowledge of representation for events that recognizes a high consistency of expectation.

Furthermore, he emphasizes the point of "script" of carrying the general knowledge of representation for events that recognizes a high consistency of expectation (Lucariello, 1994). In other words, Ella perceives her marriage without any certain expectation.

The question then is whether a marriage, in which Ella has no expectation in her marriage while it always takes her happiness away, will evokes ironic tension or not. According to Muecke (1969), situational irony refers to situation that contradictory between expectation and reality. Ella's marriage is situational irony because it does not only evoke situation that felt ironic but also it is implemented the contrary of Ella's expectation and the reality. In the narrative, Ella is not vividly exposing her expectation for her marriage otherwise her marriage leads to her ironic destiny. Marriage is presented as "the script" in this story which carries the "common expectation" of marriage as something with cultural values. This is presented as "a virtue which all good mothers teach" (pp.3) that implies the way Ella perceived the value of marriage as something communal. For those reason, the event of Ella gets "gold, silver, or lead" as the representation of wealth and well-being is sufficed result for the common expectation of marital life. However, for Ella herself, the reality is she has trapped in unhappy marriage as "a vague conclusion" (pp.3). This result obviously contradicts from the expectation. The marriage becomes exhaustedly ironic situations because it brings a distressful for Ella that she never expected. The unexpected result that felt ironic is shown as "pitying herself" caused her decision to "letting her delicate and ethereal emotions" only through "imaginative occupation, day-dreams, and night-sights" that always under her anxiety and thinking of her husband would never be known and disturbed (pp.3). Because of these conditions, Ella tries to suffer her marital life through poetic creation that is adequate for her refinement way (pp.6).

Similar to marriage institutions, Ella's poetic works are also represented as the ironic event. The fictional world within "An Imaginative Woman," by emphasizing the typical Victorian era of women's inferiority, shows Ella's poetic creation is positioned below male superiority. Ella gets her works published in "obscure magazines" with "her effusion at the 
bottom, in smallish print" (pp.6). This apparently shows how Ella is treated in her life and her poetic ability. Above all, Ella gets the achievement of some published works but sadly are under her pseudonym "John Ivy." This sustains a poor judgment over Ella's ability in making poems if she appeared as her own gender. In short, ironic tension is conveyed through an underestimation of Ella's poetic ability which is an exemplification of unfairness (Li, 2008).

However, poetic works shared similarities as "carrying no expectation" as like marital institution does over Ella. Ella decides to render her poetic creation as the best way of refreshing and healing from her "stagnation caused by the routine of a practical household and the gloom of bearing children to a commonplace father" (pp.6). In other words, throughout the story, she is never explicitly seen as supposed to be a well-known poet. Accordingly, the fact that Ella has been mentioned as an appearing poet in some magazines gives nothing special until she had accidentally "met" with a poet she admires, Robert Trewe. This unexpected event implies Ella's poetic ability (even it cannot compete with the male poet) is still considerably decent especially in the Victorian era that was surrounded with no space for women outside their domesticated field of household or nursemaid (Hughes, 2014). Moreover, Ella surprisingly cannot believe her poetic ability although the narrator has praised her as "[Ella] was more than a mere multiplier of her kind..." (pp.7) shows that she does not expect a particular achievement. This unexpected triumph still suggested the ironic situation because the win belongs to one of ironic features (Lucariello, 1994). Lucariello's (1994) concept of ironic situation inserts win as one important aspect that means someone inadvertently or unintendedly wins the outcome.

To sum up, marriage and poetic creation correlate with each other as a versatile element for establishing the ironic set of plots. The major path of the story is made from the sequences of ironic events which focus on Ella's position as the target of these ironic circumstances. From the marriage, Ella has suggested the best reason for her repressed situation, then as the released cure, poetic creation is offered to suit as the best way because it corresponds with Ella's tendency and characters. However, poetic creation becomes an interesting event because it turns its positive impact into subsequent ironic events. The shift in impact occurred because of Ella's decision to become a poet and to love poetry. In Ella's opinion, all of which is happening is her cruel fate. Ella indecisively stultified her condition and follows the path to be the victim of irony that presented seems to be her fate or designated virtue. According to Nelson (2010), victims of irony are characterized by their sense of deserve the irony as their fate that links to their unawareness or confidently ignorance of what happened upon them.

\subsubsection{Victimization Character}

\section{Ella Victimization}

In the story, Ella is obviously portrayed as a targeted victim of ironic situations. This is underlined throughout interrelation between coincidences and frustrated meetings. Once Ella is told by the landlady, Mrs. Hooper, that Trewe makes plan to take some books from the room which Ella's take. Ella feels overjoyed which she "goes to bed of musing him" (p.13). However, the next day, Trewe deliver the messages saying that he cancelled his plan of taking his book because he does not oblige them. This accident causes Ella to be despondent. Afterward, Trewe says that he will call since he is staying with his friend in the neighborhood, otherwise he never calls. As the time to coming back home, Ella decides to make attempt to meet Trewe at his place on the nearby island. However, because of Ella has not brave enough to call him and ask the 
accurate address of him, the meeting is stultified, and Ella sadly goes back. The next attempt of meeting Trewe is failed due to Trewe's unforeseen decision to cancel his visit to Ella's house. Ella is afflicted of "blithe and buoyant" (pp.22). Then, the most tragic moment of frustrated meeting occurs when Ella read about Trewe's suicide and realize her wanting to meet the poet will never be happened. This represents that coincidences and frustrated meeting works headto-head in establishing Ella's sense abstruseness of "grief and distraction shook her" and "frenzy of sorrow" situations (pp.26). Those coincidental events make the sequence of ironic situation that haunt Ella.

Coincidences work as Ella's supplier of desire and eagerness towards Trewe. These events give her extraordinary amusement from the marital boredom. Ella believes that her coincident published work in the same magazine with Trewe and staycation in his room suggests her fate to know, meet, and make relation with him. Ella's belief about coincidences transcends its meaning that fits Jung's synchronicity theory of a "meaningful coincidence" with a specific status as indicators of an "a causal connecting principle" (Coleman, Beitman, \& Elif, 2009: 266). This connection is pursuant to Ella as embodiment of her destiny with Trewe. Thus, she translates the interwoven fate with Trewe in strong effect and impression of personal attachment that she relishes as:

[In] the natural way of passion under the too practical conditions which civilization has devised for its fruition, her husband's love for her had not survived, except in the form of fitful friendship, any more than, or even so much as, her own for him; and, being a woman of very living ardours, that required sustenance of some sort, they were beginning to feed of this chancing material, which was, indeed, of quality far better than chance usually offers. (pp.10).

Subsequently, the effort to determine these coincidences leads Ella to follow the "coincident intention path" to realize her feelings and sense. Ella innocently works hard to satisfy her designated fate that comes from several coincidences with Trewe. This is due to further reaction from determining coincidence. Meanwhile, several frustrated meetings appear as opponents and contrary to her effort which means the tragedy upon Ella. Ella has never survived from her shackles of grief until she is not capable to "get further than for very exhaustion" then get a "sudden collapse" that cut off her life. Thus, coincidences are put to achieve tragic effect (Firth, 1960).

The events of the cancelled meeting come along with Ella's eagerness of her "delicate fate" from coincidences. These events emerge as if they defeat Ella's effort. The books that are not taken, the place, which is never to be attended in, and the fans that never be known come one by one in certain order to break Ella's established enthusiasm and indeed emphasizes a transcendent power. Due to those perceptions, Ella considers ironic fate and ethereal power that never allow her to obtain her eagerness and indulgence. Thus, Ella's languishing of all those painful realities is shed through the way she treats her children (pp. 13; pp. 24). Ella strangely treats her kids that evoked from Ella's losing power for herself and her life. It refers to certain higher-level agents with an overwhelming tendency that inch by inch puts Ella down even though she has tried to defeat. The constellation of frustrated meetings is a manifestation of cosmic power that represents certain higher power which is perceived primarily by the victim, Ella. This is highlighted due to tragic events of Trewe's suicide which makes Ella proclaims, "God is a jealous God; and that happiness was not for him and me!" (pp.) as actualization of her losing hope and failing against her tragic fate. According to Tittler (1985), the agent who makes work of cosmic irony is determined by the force that its presence is 
defined as an entity which has not to be manifested as persona. To sum, Ella's victimization is made of her choice to determine coincidences and believe of her straighten to make it happen, but she never be allowed by the cosmic forces that presented as designated cancelled meeting.

\section{Trewe Victimization}

Trewe is characterized with higher in pity and misery than of William. On one hand, he is portrayed as the poet that has qualified to be adored especially towards Ella's perspective. On the other hand, Trewe's characterization is under the sense of loneliness, missing, and misery. Indeed, Trewe's physical appearances also emphasizes it by “... the large dark eyes... showed an unlimited capacity for misery..." (pp.15). He is "mostly writing and reading and doesn't see many people" (pp. 8). His life is seemed to in the outraged that he enjoys staying whenever "there is not a soul in the place" (pp. 5). The extraneous life, then stimulates Trewe of longing love and affection from women that he never got (pp.26). Because of this gloomy life, Trewe writes poem in his style and form that rarely different from society taste. The way Trewe lives and his loneliness lead at his decision of committing suicide caused of painful criticism. Trewe's tragic ending accordingly presents his victimization.

In addition, Trewe is characterized by solitude. Trewe mostly feels the pains of loneliness and the insufficiency of a divided nature that is an important characteristic of a tragic victim (Russo, 1936). When the condition is gained to be worst because of his works is criticized as "too erotic and passionate," Trewe's later action is shown as he perceives the critique in tragic sense. Accordingly, Trewe's ends his "fair attack" with his "powerless to refute and stop" "by shooting himself with a revolver" (pp.25). His action is typical of a tragic character with subdued frustration and the falling of man out of his power (Russo, 1936). Furthermore, Trewe characterization is suitable to engage the purpose of the tragic irony that of complete frustration, the downfall, and deadlock (Russo, 1936). In other words, Trewe has been dedicated to the victims of tragedy.

Above all, one important point of Trewe's victimization as victims of tragic irony is due to his lack opportunity to defeat or act by his hands. In contrast to Ella's victimization model, he is attributed to be targeted to all the happening for him. Trewe is formed of pure victim character that makes him as pathetic character, not tragic character. According to Spivey (1954) there is a difference between tragic characters and pathetic ones that relates to defiance intention towards the fate force. His victimization is also represented his duty for emphasizing Ella's signification of ironic victim. By depicting another typical victim, Trewe's victimization permits lower level than Ella's victimization. Both Ella and Trewe are typical victim by the doom and designated destructive virtue, but Trewe is presented weaker than Ella for craving the changed destiny. His character is too fully ignorance and acceptance features.

\section{William Victimization}

William's victimization is postponed until approaching the end of the story. In the beginning, William is represented as an agent who confronts the main character, Ella

Marchmill. His significance in the story is linked with Ella in aiming to establish Ella's story of irony. This is because William is the husband that Ella is ungrateful to be with (pp.3). Besides, William is characterized with a lack of embracing feeling and emotions, and a completely opposite Trewe that makes Ella strongly interested in Trewe rather than William (pp.2). William is also presented as a man who is equable, lymphatic, sordid and material that makes 
him "supremely satisfied with the condition of sublunary things. All of which William's characterization is presented as something that Ella dislikes and opposites from her typical man. Thus, to be lived with William as wife makes Ella feel the irony of life. Moreover, throughout the story, his name has been mentioned five times, far fewer than Trewe with thirty-five times. This implies the minimum attention that drags into William.

However, at the end of the story, all of William's representative figure is turned over into something that struck the audience with his awareness of Ella's behavior towards poetic inclination and Solentsea (pp.28). This event makes readers' assumptions towards his position twisted. But readers' reveal that William's awareness is nonetheless his lack of knowledge of what actually happened. William believes that his own child is the child from Ella's affair with Trewe (pp.31) while readers know that William is supposed to be tricked. This makes William the object of victim of dramatic irony because it evokes intensified emotional effect for readers through perceived sense of irony (Firth, 1960). Accordingly, the delayed revelation of William's awareness is made with a certain purpose that evokes the dramatic tension.

However, there is not only one dramatic tension through William's role in the story. At first, readers get less information upon William's awareness of his surrounding situation, especially about his wife. Readers have been trapped by William's characterization from the story line that William is known more. This means, at the beginning, readers are being the victim from the narrative of William's characterization. But then, at the end of the story, the dramatic tension comes with the reader comprehending more information than William has. These coupled dramatic with twisted knowledge of information posits William as the object of dramatic irony because his victimization is revealed at the butt of the event (Muecke, 1969; Lucariello, 1994).

Subsequently, William is supposed to be the dramatic victim because readers have surpassed his twisted knowledge. Readers are privileged with their position that is distanced as an external part of the story. According to Goldie (2007) by taking perspective from outer, readers can get the view over William's story who has tricked with more benefit. The benefit to take time and pay attention to the story is the important aspect of the dramatic tension (Goldie, 2007). William victimization invites the correlation between reader, character and narrator that establishes the perspective which is not taken within the fictional world, but it is expanded in narrative level. Thus, the interplay which is offered by William's victimization has exceeded from story level into narrative level.

\subsection{Narrative Level of Irony}

The advent of Ella's fixed internal focalization works together with multiple internal focalizations-William, landlady, and painter, in order to enhance specified readers' perspectival view. Besides, there is also presented external focalization in lesser amounts and least use of zero focalization. The numerous focalizations in this narrative shows disparaging perspectives among characters and inherently makes such ironic distance among characters, narrator, and readers. Accordingly, this deliberation of the story is represented in ironic intention which indicates the upper level of irony (Muecke, 1982). The way vocalizations deliberate the upper level of irony indicates the ironic manner which is represented in the narrative level (Genette, 1980). 


\section{Fixed Internal Focalization}

Ella Marchmill is the main female that leads the readers into the story of her predominately ironic life. The portrayal of her fixed internal focalization is taken from several subjects that she has focalized. There are Ella's pessimism of marriage and poetical achievement, the sexual urges, and the sorrowful of fate. Additionally, because she often shows her appearance as a focalizing character, therefore, it is apparently presented in Ella's fixed internal focalization in this narrative of "An Imaginative Woman."

Ella shares her pessimism over her inclination of imagination, daydreams and nigh sigh as the troublemaker for her marriage especially towards her husband "...which perhaps would not much have disturbed William if he had known of them" (pp.3). Besides, Ella also explicates her pessimism towards poetic achievement of her planning to make a concise volume that "[A] ruinous charge was made for costs of publication; a few reviews noticed her poor little volume; but nobody talked of it, nobody bought it, and it fell dead in a fortnight-if it had ever been alive." (pp.7). Ella's suspicious consideration relays on her "thoughts were diverted to another groove just then by the discovery that she was going to have a third child ... it might have done if she had been domestically unoccupied." (pp.7). Moreover, Ella's status of being mother, wife, and woman in Victorian era insists her unenthusiastic thought of her own indulges. The cultural boundaries hold the reason for Ella's deceiving the gloominess. This is internally occupied in Ella's mind that focalized to shows how she perceived in such situation. This internal focalization presents the context of Ella's situations and her reaction towards her situation that based on her considerably thought.

Interplaying of a certain situation and its reaction permits an identical feature for the character. This work intimately affects a character's certain style or identity which is delivered through the narrating. Then, the focalizer agent is no more than the character itself who suffers and perceives the situation. The direct "communication" from the focalizer as the character's filter agent has been taken by the character as the focalizer by her delivered innate mind and thought. Accordingly, the internal focalization obtains the side by side between character and reader.

Besides the arousing pessimistic sense, Ella deliberately expresses her sexual urges to satisfy her direct communication with readers. Ella has roundly mindful conditions by the way she shared her sexual urges exploration. For the preliminary, Ella describes how the sexual motivation has indulges her.

"Ella Marchmill flushed without knowing why, and suddenly wished her companion would go away, now that the information was imparted. An indescribable consciousness of personal interest rather than literary made her anxious to read the inscription alone; and she accordingly waited till she could do so, with a sense that a great store emotion would be enjoyed in the act." (pp.9).

Ella is consciously aware of something that hits her because she follows up on what she thinks she wants to do. The matter of "without knowing why" and "indescribable consciousness" does not refer to their definitive meaning rather to stimulate readers' curiosity like Ella's curiosity. The interesting sense then becomes the major reason to take for granted Ella's reaction of waiting until she can afford her personal interest. Thus, Ella bids readers to excessively enjoy "a sense that a great store emotion" from that reaction. Furthermore, 
exaggerates the intense of curiosity by pretend as the fully naïve of determining "[T]he personal element in the magnetic attraction exercised by this circumambient, unapproachable master of hers was so much stronger than the intellectual and abstract that she could not understand it" (pp.10) which overtly presented a sexual urge.

The probability of Ella not pretending to be naïve is presented even in small amounts. This is because readers have surpassed Ella's knowledge through the situations and Ella's action to react to those situations. Ella's growing personal interest and her action becomes the apparent reason for readers to perceive the information. There are several evidences, the way Ella worshipping Trewe's blanket, "The mantle of Elijah!" and Trewe's hat "His heart had beat inside that coat, and his brain had worked under that hat at levels of thought she would never reach." (pp.10). All of those appraisals are proclaimed identically from Ella's perspective. However, those have different levels of representation into the readers.

The first one is presented by direct speech that uses Ella's voice. The homodiegetic level by this direct speech runs more impactful to enterprise the direct communication rather than the presented by third pronoun. However, to achieve direct communication, all of those styles are combined with sufficient enough in reaching readers' attention. In addition, to strengthen the direct relation, Ella takes several focalizations that show the process of the personal interest which affects her emotions. Her personal excitement "with a serene sense of something ecstatic" (pp.14) that she cannot complete makes "her feel quite sick" (pp.10) that stimulates her feeling for her children "half as much as usual" (pp.12). The identical type of Ella focalized point is trying to hold readers attention by making the content of her situational context which permits her to do the proposed reaction. The process of Ella to analyze and observe her own feeling from "the unknown and indescribable" into the emotional configuration becomes the center point of the content of Ella's focalization. The purpose of emerging her sexual urges is aiming to drag not only readers' focus throughout the narrative but also their perspectival discovery.

Readers' perspective is designated in direct communication by Ella's focalization. Because Ella has exposed her inner thought and perspective towards her eagerness for Trewe as something that hits her emotional cultivation, readers' takes for granted the information all of them. Moreover, the emotional configuration is presented by the time Ella faces her sorrow of life. Since the life is not sufficiently confront Ella's happiness, the sorrowful of her life and fate is deliberately through Ella's direct speech "What a useless journey it was!" (pp.20) and "God is a jealous God; and that happiness was not for him and me!" (pp. 26) truly makes sense. The "journey" of Ella satisfying her personal interest has found the doom of all cancelled meetings. Above all, her own life journey also receives the sad ending of due to Trewe's suicide and her own death. Thus, the emotional configuration is apparently delivered throughout Ella's focalization.

Additionally, to reinforce the position of character-focalizer, Ella has appeared using free indirect speech. Ella has shared of the "thought how wicked she was of a woman having a husband and three children to let her mind stray to a stranger in this unconscionable manner" with the focalizer. However, it shows that the focalizer has let readers know through her lens beneath Ella's thought. This shared stage between Ella and the focalizer is grabbed by Ella's acclamation "[No!] He was not a stranger!" which shows Ella's shift of presence level. An endeavor to build meta-interaction brings compatible relations that Emma Kafalenos' (2006) 
explanation of readers' important step for interpretative process. Emma highlights the point of readers' contribution in constructing the narrative world through cognitive and emotional engagement (Kafalenos, 2006). Like the previous part of the pessimistic voice, Ella shows her voice remarked by using her lyrical statements, especially in the way she denounces her sexual endurance experience to evoke readers' affective experience. Sharing sexual experience is internally focalized that run on the gender inequality and shared beneath the relationship between Ella and the readers only.

Fortunately, the closeness makes it easy to transfer Ella' emotional and ideological facets. This is because all of those sight and perception are exclusively perceived by Ella and only shared to whoever stands beside her which is the reader that is informed through her focalization. Due to those reasons, readers are commonly accompanying her sight and derive the same perception. Regardless of overshared ironic temptation, Ella's fixed internal focalization fits what called by (Ryan, 2018) as demanding its aim to achieve reader's cognitive mapping for perception acceptance to the narrative. This causes the importance of who says or narrates the perception upon the event (Bal \& Lewin, 1983).

The perplexed autonomous perception then is obligatory occupied into both Ella and readers since allowing a severe distance from the narrator. Ella's internal focalization is mean to her disparaging place from the narrator's authority. This case indicates her independent status as a fictional character that arises as an identical realty entity. However, her imparted role as the main brave character invites readers' emotional and cognitive impulse to share the plate. Thus, Ella's self-determination, all its significations, and the ironical sphere are also perceived equally to the readers. Acknowledging self-determinism, according to Deci and Ryan (2009), sometimes insert a self-intriguing inside people's mind. Self-intriguing is held by the powerful belief against another alternative or choice that comes up side by side with the belief. Ella's self-determination is an observable enunciation for her fixed internal focalization. This covers up Ella's cognitive, psychological, and emotional cultivation of her surroundings. Therefore, it excludes the reader's motive to comprehend Ella's perspective. Ella's figure of the main lead character stimulates readers' perception through her static focalization of selfdetermination that, based Salem, Weskott, and Holler (2017: 2), is defined as might enforce readers to employ indeed a vantage point over the protagonist and encompass her "emotional, social, political, and ethical attitudes." In short, Ella fixed internal focalization is a suitable way for readers' privileged status to comprehend the ironic situation from above.

\section{Multiple Internal Focalization}

Besides Ella Marchmill presents as character-focalization, there are several minor characters who take part as focalizer. However, all of those focalizer have the same focalized object, Robert Trewe. For the landlady he is "a different sort of young man from most," "a poet.... and he has a little income of his own, which is enough to write verses on, but not enough for cutting figure, even if he cared to" (pp.5). And for painter (William's friend's brother) he is "a curious, a very good fellow, [and] a warm friend," whose poetry "is rather too erotic and passionate... for some taste" (pp. 26-27). The minor character becomes the focalizer agent because they deliver their point of view towards Trewe's character. Those two agents also participate to add information that can be accessed by Ella. The landlady and the painter not only presented the same focalized object, but also the same insight of the same object; Trewe's personality and his poetic achievement. Thus, their focalization is determined as repetitive 
multiple focalizations. The result of repetitive multiple focalizations is perspectivation mapping for readers towards a certain character or point that becomes the core of focalization object (Bae, Cheong, \& Young, 2011a). Accordingly, readers take a certain perspective of Trewe's characterization from several perspectives that are taken from those focalizer agents.

Besides those multiple focalization-landlady and the painter, Trewe's presence as the object is presented through William's focalization. William subdues his uncomfortable attitude that is not explicitly, and not so much exposed. The way he murmured '... Bless his picturesque heart!' (pp. 18) over the poet's photograph, “...of course I am not jealous of this unfortunate man" cause Ella's flee to his funeral, and "...the dreamy and peculiar expression of the poet's face sat" (pp. 32) upon his resemblance's observation, refers to Trewe's position as the object. Take different style of the content towards focalized object, William has not enunciated about Trewe's characters rather than his judgment for Trewe. Using several identical verb of negative arbiter "picturesque" and "unfortunate," William presents the tendency of his unlikeness towards Trewe. Here, William's focalization does not stand a line with the land-lady and the painter that seems remains assertion of objective point of view. A main point from William's focalization remarks subjectively arranged to give different perspective towards perspectivization mapping of Trewe's character.

Readers are invited to determine Trewe, as focalized agent, from the perspectivization. Thus, in order to enrich readers' information for perspectivization, the number of focal agents is foremost point. Due to this vitality, Ella takes a part to be the focalizing agent. From previous part, Ella visibly becomes the most focal agent by her fixed internal focalization who wideawake of Trewe's fictional presence. However, in this part, the highlight point is Ella's focalization that obviously displays Trewe's as the object. In this case, Trewe is not presented as the focalized agent but the materialized object in fictional world. His appearance is restrained through inanimate object like mantel and hat (in previous sub-topic), photograph, lock hair, tombstone, and letter. Dealing with Trewe's lock-hair, the implacable of this artifact appears as the speculated point for both Ella and William. In one side, Ella concords this lock of hair as the material that conjoint her realistic trickery with her poetical imagination.

Ella wept over the portrait and secured it in her private drawer; the lock of hair she tied with white ribbon and put in her bosom, whence she drew it and kissed it every now and then in some unobserved nock (pp.27).

While on the other side, the artifact presents as the vivid material object to William's perceptible reality and subjective objection.

Marchmill looked long and musingly at the hair and portrait, for something struck him. Fetching the little boy who had been the death of his mother, now a noisy toddler, he took him on his knee, held the lock of hair against the child's head, and set up the photograph on the table behind, so that he could closely compare the features each countenance presented. There were undoubtedly strong traces of resemblance; the dreamy and peculiar expression of the poet's face sat, as the transmitted idea, upon the child's and the hair was of the same hue (pp.32).

The result of Ella and William's differing perception fits the idea of contrastive perpsectivication as work of multiple internal focalizations to evoke the dramatic tension. In addition, Ella and William's focalization expands readers' information rearrangement to raise 
their cognitive perspectivization. The diversity of perspective from several focalizer agents plays an important role to this duty (Göran, 2002). Besides, one more chief component in the narrative that enhances perspectivization is through Trewe's own focalization. Once Trewe has appeared in extradiegetic level through her conversation with landlady:

He belongs rightly to that frame, which I bought on purpose; but as he went away, he said: "cover me up from those strangers that are coming, for God's sake. I don't want them staring at me, and I am sure they won't want me staring at them." So, I slipped in the Duke and Duchess temporarily in front of him, as they had no frame, and Royalties are more suitable for letting furnished than a private young man (pp.13).

His focalization also emerged in an embodiment of his hand-writing letter:

Dear,- Before these lines reach your hands I shall be delivered from the inconveniences of seeing, hearing, and knowing more of the things around me. I will not trouble you by giving my reasons for the step I have taken, though I can assure you they were sound and logical. Perhaps had I been blessed with a mother, or a sister, or a female friend of another sort tenderly devoted to me, I might have thought it worth-while to continue my present existence. I have long dreamt of such an unattainable creature, as you know, and she, thus undiscoverable, elusive one, inspired my last volume; the imaginary woman alone, for, in spite of what has been said in some quarters, there is no real woman behind the title. She has continued to the last unrevealed, unmet, unwon. I think it desirable to mention this in order that no blame may attach to any real woman as having been the cause of may [decease] by cruel or cavalier treatment of me. Tell my landlady that I am sorry to have caused her this unpleasantness; but my occupancy of the rooms will soon be forgotten. There are ample funds in my name at the bank to pay all expenses. R. TREWE. (pp. 2526).

Subsequently, Trewe's status of focalized agent is arguably changed into focalizer agent by the inanimate object becomes the further question. The way Trewe's presence within land-lady focalization indicates the shift of narrative level. The time when narrative level is shifted, it indicates the shift of the focalizer agent (Nkamanyang, 2008). The direct discourse of narrating-I genuinely refers to the original content of the focalizer subject that character is the subject (Nkamanyang, 2008). Besides, the letter remains bringing a certain purpose towards readers. Letters addressed a special effect of readers' attention. This attention is presented like a bridge that connects readers and the innermost of the character (Nkamanyang, 2008). Trewe's letter becomes the compatible device to reveal her thought and feeling "of an imaginative woman." Moreover, within the letter, Trewe uncovers her inner personality, the several reasons for his alienating inclination and his sense for making his poems. Through the letter, Trewe communicates about his behavior and his rational thoughts that will make readers understand him.

From those several styles of internal focalization, it implies a hierarchical level from focalizer and focalized agents. The focalized agent is the object of the focalizer subject. The hierarchical level downward the implicated object. In Ella's internal focalization, her status as the subject that has focalized several objects indicates the higher level from Trewe who has been focalized by other characters. The distance between each stage of those levels refers to the disparity of knowledge among characters. However, all of those focalizations that stand 
under the "internal focalization" umbrella leads to readers' access towards character perception configuration.

\section{External Focalization}

Within the narrative, this portrays a few external focalizations. Firstly, it is displayed by Ella's appearance as the object that is seen by the focalizer while the focalizer cannot comprehend what is going on or going to be done by her. This is portrayed "As she gazed long at the portrait she fell into thought, till her eyes filled with tears, and she touched the cardboard with her lips. Then she laughed with a nervous lightness and wiped her eyes" (pp.15). The presentation of Ella's deed towards Trewe's photograph accomplishes readers' information of the narrating Ella's action. The narration presents what readers might see upon Ella but cannot deeply see-through Ella's be experiencing those actions. Focalizer presence is in the external territory of Ella that she lets only the narrating process without any perception is permeated out through focalization. Ella is close enough with the narrator rather than the focalizer. Through the external lens, the focalizer may perceive Ella's action only the outwards manifestations of her which is presented. This external focalization is presented by Ella's situation that is rendered from self-experience.

The second, external focalization also takes part beneath William's action.

$\mathrm{He}$, too, was aware that suicide had taken place recently at the house they had occupied at Solentsea. Having seen the volume of the poems in his wife's hand of late, and heard fragments of the landlady's conversation about Trewe when they were her tenants, he all at once said to himself; "Why of course it's he! How the devil did she get to know him? What sly animals women are!" (pp.28).

William is seen from the focalizer, yet the focalizer cannot comprehend the actual significance and relation between the manifestation of William's situation and his reaction. In this case, accordingly, the focalizer has a retrospective sight that includes William's past when at Solentsea house, and the present time of William uttering revilement for his wife. The disposal of the temporal dimension that is taken by the focalizer is determined to be external or outward from the character (Rimmon-Kenan, 2005). This external position, moreover, also means lackof synchronization among the focalizer and the character.

There are a few external focalizations within the narrative of "An Imaginative Woman." The purpose of the little use of this type of focalization deals with the significance of the narrator's unrestricted knowledge. External focalization evokes narrators' versatile capability of knowing everything about the represented world that is not leased from character orientation (Rimmon-Kenan, 2005). Because it is not limitedly taken from character, rather than the contextual determination, this allows readers to know as much as the narrator knows. Then, the characters' encouragement for the readers through internal focalization will be powerless. Thus, the few of this external focalization is aimed to keep readers' intimate relation with characters.

\subsubsection{Ironic Intrusive Narrator}

In the narrative, there are presented Ella and William polarized distinction characters. This part of the narrative delivers the general information about Ella and William (pp.2). There is an obvious narrator voice that deliberates the characters' figure. Manifesting the narrator voice comes from the linier pinpoint between Ella's "nervous and sanguine" and William's 
"equable and lymphatic" without going through any perspective neither of character or the narrator. There is no access for getting any perspective because there is nothing cognitive sphere, emotional cultivation, and mental estimation within what is told by the narrator. Moreover, the contrary personalization of William considers "his wife's likes and inclination somewhat silly," while Ella considers her husband's "sordid and material" enriches their characterization. Therefore, it infers to zero focalization because it enlarges the image of characters with all-round information (Xu, 2020: 485).

It obviously represented zero focalization with all surrounded criteria of must have no certain perspective, foregrounded center of interest, and apparent organizing principle (Jahn, 2007). Because it carries any attitude or expressive impression, zero focalization is determined as the narrator's vocal. It can be defined as a narrator taking the place of telling the story, not showing. For that reason, this part is offered as part of "pure narrating" from the narrator (Genette, 1988). However, there is struck placement of simile of "a votary of the muse" which as the "best" Ella's characterization that turns around the omniscient point of view (pp2). The inserted comment is not changing the narrator's position physically in the fictional world, but it transmits a sort of value for the preliminary description to Ella's characterization.

Besides Ella's characterization, narrator's comments are perceived towards Ella's poetic creation as "... though less than a poet of her century, [Ella] was more than a mere multiplier of her kind..." (pp.7), and Trewe's poetic creation that portrayed below:
Trewe's verse contrasted with that of the rank and file of recent minor poets in being impassioned rather than ingenious, luxuriant rather than finished. Neither symbolist nor decadent, he was a pessimist in so far as that character applies to a man who looks at the worst contingencies as well as the best in the human condition. Being little attracted by excellences of form and rhythm apart from content, he sometimes, when feeling outran his artistic speed, perpetrated sonnets in the loosely rhymed Elizabethan fashion, which every right-minded reviewer said he ought not to have done (pp.6).

The term "contrasted" with the superlative adjectives of "rather than" and "more than" show how the narrator is treating and assessing Ella and Trewe's poetic ability. The openly narrator's comment on Trewe's talent simulates readers' attention to the narrator's perspective. Moreover, the uttered comments are about poetic creation that implies that the narrator is interested in poetry. The description of; "impassioned" its content of "symbolist," poetic structure of "excellence of form and rhythm," the poetry style such "Elizabethan fashion" are tangible evidence of the narrator interest in poetry or at least knowledgeable of poetry. The comment towards poetic creation carries a certain sign of his belief in poetry. Narrator seemingly stands in support of Ella's female poetic creation but extremely criticizes Trewe's ability. This sign credits to his intrusiveness for readers' detachment in the narrative.

Based on Rimmon-Kenan (2005), the level of narrator personification is related to the perceptibility of a narrator. However, the fact that inserted comment determines not only the narrator's semantic position in the narrating process but also it carries such a perceived attitude or intention. The accepted sense or attitude is based on the comments inserted, which influence the coherence of the overall way of narrating process that fits Keen's arguments that the accuracy of the narrative circumstance is what determines the narrator's reliability (2003, cited in Mamo, 2010). Narrator tendency of portraying Ella and Trewe with asserting particular attitudes tries to outline the way readers will follow and recognize a diegetic reality that 
contrasts the narrator's accounts. By inserting subjective perspective through forming of narrated comments, the narrator is associated with establishing unreliable narration (Brütsch, 2015).

Unreliable narration, subsequently, emphasizes discrepancy between narrator and readers. According to Brütsch (2015), the discrepancy is assembled from between readers privileged towards the narrator's implicit determination. Readers can comprehend an implicit meaning that is odd with the narrator's account (Brütsch, 2015). On the other hand, Walsh (1997) explains the narrator's personal extra-impression is not on the outside of his account of narrating because the narrator must report, not observe. Walsh (1997: 6) insists that the narrator's perception is attributed to "precisely narrating." This is true that the narrator is practically not ironic in asserting the perception, but the incongruity from his comments from narrative text as a whole that shaped suggesting opposite interpretation evokes the ironic tension.

The erroneous judgment towards the narrator's uttering his special attention for Ella's and Trewe's poetic creation stultifies ironic unreliable narration. The ironic unreliable narration, moreover, enhances readers' awareness towards the whole narrative of "An Imaginative Woman" as something more than excessive twisted knowledge. From the story level, readers comprehend how character and the structured events are framing the irony in the lower level which is identically indicated by the characters naïve. Meanwhile, in narrative level, playing with focalizations designates readers to perceive suggested focalizer-agents' evaluation or representation which embarks on an upper level of irony in suggesting readers privilege as observers. However, the narrator's intrusiveness struck the harmony of situational irony due to unreliable narration. This unreliability narration, thus, accentuates the ironic tension in metanarrative.

\section{Conclusion}

By constructing situational irony in the narrative of "An Imaginative Woman," it is concluded that the collaboration among sequence of ironic events and victimization characters allows the intention of irony as the embedded aspect in the story. The depiction of those aspects cooperates to establish an apparent irony in the story level. Furthermore, the empowering ironic intention is taken from the irony in narrative level in which the way irony is represented. By formulating focalizations and intrusive narrators, there is an ironic manner among characters as focalizer and narrator that delivered towards readers' comprehensive observation.

The way of presenting situational irony is confessed as not only of the subject to portray but also as the way it is perceived and comprehend, drives the modern attitude. The use of numerous focalizations; internal, external, and zero focalization, indicates the multiple lenses of perspective and perception that aim to appeal to the reader's sense of the irony. Moreover, it is prominent that situational irony offers several advantage points related to its implication in narrative. They are presented as 1) the best way to establish the sense of irony to the readers; 2) includes the verbal irony in a form of implied author or narrator's comment; 3) the suitable techniques to intensify the ironic experiences in a form of the ironic attitude of the author towards the story and characters; 4) covers up all the various dramatic irony used: cosmic, life, tragic irony. 
In the end, the result of this study suggests that academia, literature enthusiasts, shortstory writers, poets, and critics understand the way of irony in the very essence of discrepancy and sense of justice in the narrative structure and form. The requirement of knowledge of situational irony provides a possible way to construct, reconstruct, and comprehend certain ideological values. This examination is not claimed as an exemplary work of literary criticism because many flaws still exist. For those reasons, it is grave to enrich this study of short-story narrative to make a futile improvement, such as the study of hereditary or mental issues that is still scant. However, the researcher welcomes all constructive critiques and suggestions to improve and challenge this research as a part of the never-ending process of intellectual advancement.

\section{References}

Bae, B-C., Cheong, Y-G., \& Young R. M. (2011). Automated story generation with multiple internal focalizations. Paper in IEEE Conference on Computational Intelligence and Games 2011. doi: 10.1109/CIG.2011.6032009

Bae, B-C., Cheong, Y-G., \& Young R. M. (2011). Toward a computational model of focalization in narrative. Proceedings of the $6^{\text {th }}$ International Conference on Foundations of Digital Games, 313-315. doi: https://doi.org/10.1145/2159365.2159423

Bal, M., \& Lewin, J. E. (1983). The narrating and the focalizing: A theory of the agents in narrative. Style, 17(2), 234-269. Retrieved from: http://www.jstor.org/stable/42945469

Bernard, S. (2013). Women of letters and the irony of life "An Imaginative Woman" and "On the Western Circuit". FATHOM: a French e-journal of Thomas Hardy Studies, 1(2013), 1-11. doi: https://doi.org/10.4000/fathom.137

Brady, K. (1982). The short stories of Thomas Hardy. New York: St. Martin Press.

Brütsch, M. (2015). Irony, retroactivity, and ambiguity: Three kinds of "unreliable narration" In literature and film. In V. Nünning (Ed.), Unreliable narration and trustworthiness. Doi: https://doi.org/10.1515/9783110408263.221

Colebrook, C. (2004). Irony. London \& New York: Routledge.

Coleman, S. L, Beitman, B. D., \& Elif, C. (2009). Weird coincidences commonly occur. Psychiatric Annals 39(5). Retrieved from https://www.researchgate.net/publication/247914712

Čović, A. (2018). Irony in translation (Undergraduate thesis, Universitas Studiorum Jadertina, Zadar). Retrieved from https://zir.nsk.hr/en/islandora/object/unizd\%3A3395

De Jong, I. J. F. (2014). Narratology and classics: A practical guide. Oxford: Oxford University Press.

Deci, E. L., \& Ryan, R. M. (2009). The "what" And "why" Of goal pursuits: Human needs and the selfdetermination of behavior. Psychology Inquiry, 11(4) 227-268. doi: https://doi.org/10.1207/S15327965PLI1104_01

Firth, J. J. (1960). Thomas Hardy-Victorian and modern ironist (Doctoral dissertation, University of Ottawa, Canada). doi: http://dx.doi.org/10.20381/ruor-8937

Fludernik, M. (2004). An introduction to narratology (P. Hausler-Greenfield \& M. Fludernik, Trans.). London \& New York: Routledge Taylor and Francis Group.

Genette, G. (1980). Narrative discourse: An essay in method (J. E Lewin, Trans.). Ithaca: Cornell University Press. Genette, G. (1988). Narrative discourse revisited (J. E. Lewin, Trans.). Ithaca: Cornell University Press.

Ginsburg, M. P. (2012). Imagination, poetic creation, and gender: Hardy's “Imaginative Woman." Modern Philology, 110(2), 273-288. Retrieved from https://www.journals.uchicago.edu/doi/pdf/10.1086/668446 
Goldie, P. (2007). Dramatic irony, narrative, and external perspective. Royal Institute of Philosophy Supplement, 60, 69-84. doi:10.1017/S1358246100009619

Göran, N. (2002). Focalization and narration: Theoretical and terminological refinements. Poetics Today, 23(4), 685-697. doi: https://doi.org/10.1215/03335372-23-4-685

Hardy, T. (1912.) Wessex Tales. London and New York: Macmillan and Co.

Hardy, T. (1927). Life's Little Ironies. London and New York: Macmillan and Co.

Hasan, N. (1982). Thomas Hardy: The sociological imagination. London: The Macmillan Press Ltd.

Hughes, K. (2014). Gender roles in the 19th century. Retrieved from https://www.bl.uk/romantics-andvictorians/articles/gender-roles-in-the-19th-century\#

Jahn, M. (2007). Focalization. In D. Herman (Ed.) The Cambridge Companion to Narrative (pp. 94-108). doi: https://doi.org/10.1017/CCOL0521856965.007

Kafalenos, E. (2006). Narrative casualties. Columbus: Ohio State University Press.

Kindt, T., \& Muller, H-H. (Eds.). (2003). What is narratology? Questions and answers regarding the status of a theory. Berlin and New York: Walter de Gruyter.

Kohut, M. (2011). Gender relations in the narrative organization of four short stories by Thomas Hardy (Undergraduate thesis, Masaryk University, Czech Republic). Retrieved from https://is.muni.cz/th/eu6xi/BA_Thesis.pdf

Lanza, E. M. (2018). An exploration of female sexuality, class status, and art in Hardy's short stories. Student Publication of Gettysburg College, 613, 1-22. Retrieved from https://cupola.gettysburg.edu/student_scholarship/613/

Li, X. (2008). Irony illustrated: A cross-cultural exploration of situational irony in China and the United States. Sino-Platonic Papers, 184(October 2008). Retrieved from http://sinoplatonic.org/complete/spp184_chinese_irony.pdf

Lucariello, J. (1994). Situational irony: A concept of events gone awry. Journal of Experimental Psychology: General, 123(2), 129-145. doi: https://doi.org/10.1037/0096-3445.123.2.129

Lucariello, J., \& Mindolovich, C. (1995). The development of complex meta-representational reasoning: The case of situational irony. Cognitive Development, 10(4), 551-576. doi: https://doi.org/10.1016/08852014(95)90026-8

Mamo, T. H. (2010). Analysis of narrative voice in R. C. Binstock's Tree of Heaven (Master's thesis, Addis Ababa University, Ethiopia). Retrieved from http://213.55.95.56/handle/123456789/2970

Manzoor, S, \& Zaidi, N. (2016). Hardy's attitude towards gender issues. Gomal University Journal of Research, 31(2).

Miller, V. (2019). A king and a fool? The succession narrative as a satire. Retrieved from https://brill.com/view/title/54881

Muecke, D. C. (1969). The compass of irony. London: Methuen.

Muecke, D. C. (1982). Irony and the ironic (Revised ed.). London \& New York: Methuen \& Co.

Nelson, P. A. (2010). Irony's devices: Modes of irony from Voltaire to Camus (Doctoral dissertation, The Ohio State University, United States). $\quad$ Retrieved https://etd.ohiolink.edu/apexprod/rws_olink/r/1501/10?p10_etd_subid=71713\&clear=10

Nkamanyang, P. K. L. (2008). Forms and function of narration and focalization in some selected poems of Lord Byron: A narratological analysis (Doctoral dissertation, Justus-Liebig Universität Gießen, Germany). Retrieved from http://geb.uni-giessen.de/geb/volltexte/2010/7477/

Phelan, J. (2013). Theory and interpretation of narrative (J. Phelan, P.J. Rabinowitz, \& R. Warhol, Eds.). The Return of The Omniscient Narrator: Authorship and Authority in twenty-first century fiction. Dawson, $P$ (1972). The Ohio State University. 
Ray, M. (1997). Thomas Hardy: A textual study of the short stories. Aldershot \& Brookfield: Ashgate Publishing.

Riegler, M. (2009). Irony of fate in selected short stories by Thomas Hardy (Master's thesis, Universitat Wien, Austria). Retrieved from http://othes.univie.ac.at/3575/

Rimmon-Kenan, S. (2005). Narrative fiction: Contemporary poetics $\left(2^{\text {nd }}\right.$ ed.). London \& New York: Routledge Taylor and Francis Group.

Rudrum, D. (2002). Narratology. The literary encyclopedia: Exploring literature, history, and culture. Retrieved June 27, 2013, from http://www.litencyc.com/php/stopics.php?rec=true\&UID-1252

Russo, S. (1936). Hegel's theory of tragedy. The Open Court, 1936(3), 133-144. Retrieved from https://opensiuc.lib.siu.edu/ocj/vol1936/iss3/3

Ryan, M. (2018). Narrative mapping as cognitive activity and as active participation in storyworlds. Frontiers of Narrative Studies, 4(2), 232-247. https://doi.org/10.1515/fns-2018-0020

Salem, S., Weskott, T., \& Holler, A. (2017). Does narrative perspective influence readers' perspective-taking? An empirical study on free indirect discourse, psyco-narration, and first-person narration. Glossa: $A$ Journal of General Linguistics, 2(1), 61. doi: https://doi.org/10.5334/gjgl.225

Spivey, T. R. (1954). Thomas Hardy's tragic hero. Nineteenth Century Fiction, 9(3), 179-191. doi: https://doi.org/10.2307/3044306

Thomas, J. (2013). Thomas Hardy and desire: Conception of the self. New York: Palgrave Macmillan.

Tittler, J. (1985). Approximately irony. Modern Language Studies, 15(2), 32-46. doi: https://doi.org/10.2307/3194430

Vera, V. G. (2012). The rise of the feminine voice in Thomas Hardy's "An Imaginative Woman". White Rabbit: English Studies in Latin America, 4. Retrieved from http://letras.uc.cl/letras/whiterabbit/index.php/genres/articles/326-issue4-gomez

0Walsh, R. (1997). Who is the narrator? Poetic Today, 18(4), 495-513. doi: https://doi.org/10.2307/1773184

$0 X u, X-Y$. (2020). Characterization of Tess from the perspective of focalization. Proccedings of $5^{\text {th }}$ International Conference of Education and Social Development (ICESD 2020), 484-488. doi: $10.12783 /$ dtssehs/icesd2020/34465 